\title{
ORGANIC FARMING: A DRY LAND TECHNOLOGY FOR SUSTAINABLE AGRICULTURE
}

\author{
Dr. Nazeerudin \\ Faculty Member Centre for Rural Development Studies, \\ Bangalore University, Bangalore 56, Karnataka, India \\ DOI: https://doi.org/10.51193/IJAER.2021.7207
}

\begin{abstract}
Organic agriculture, a holistic system that focuses on improvement of soil health, use of local inputs, and relatively high-intensity use of local labor, is a favorable fit for dry lands in multi directional ways, and the dry lands offer farmer friendly technologies in rural areas of the country. In this context, a brief review on current potential of organic Farming in dry land regions is presented. It also critically examines the strategic action for promoting organic farming in dry lands. Finally concludes that, organic farming provides a solution to environmental externalities in Indian dry lands.
\end{abstract}

Keywords: organic farming, system dynamics, conversion, subsidies

\section{INTRODUCTION}

Post independence witnessing, rapid population growth in India placed great pressure on land and on these traditional farming systems; huge demands for food grains led to increased use of fertilizers and pesticides to boost production. Many of the gains in production during the last 5-6 decades resulted from the "Green Revolution," a campaign of technological interventions in agriculture widely adopted by farmers in developing countries. Expansion of irrigation to cover rain fed areas, popularization of hybrids/transgenic varieties of crops, and use of synthetic chemical fertilizers and pesticides were the major technologies promoted. This paid rich dividends in India, quadrupling food grain production from 50 million metric tons in 1950-51 to 211 million metric tons in 2001-02, and enabling India to become self-sufficient in food grain. Now a second green revolution is also in the offing, to boost agricultural production and meet the estimated requirement of 337 million metric tons by 2011-12.

Unfortunately, these positive developments have been accompanied by gradual and negative side effects such as secondary salinity, decreases in soil fertility, growing insect resistance to 
pesticides, and increased costs of production, which are challenging the sustainability of conventional agricultural production at high levels (Balak Ram 2003). Consequently, interest in organic agriculture as an ecofriendly system of cultivation is growing at both national and global levels. This shift towards organic production is supported by consumers who are aware of health hazards: demand for food grown organically is increasing by $20-25 \%$ in developed countries where awareness is comparatively high.

Organic agriculture is indeed being pursued in India; the National Programme of Organic Products (NPOP) was launched in 2000. Its aim is mainly to create certification facilities; since its inauguration, 2.5 million ha ( 6.2 million acres) have been certified as organic, providing 115 238 metric tons of produce by the end of 2004-05 (Gauri 2005). However, this produce is aimed largely at the export market, and largely uses intensive agriculture practices that are not sustainable in dry lands, where land degradation is already a serious issue. Furthermore, the dry lands also lack local food security and employment, problems that intensive monocrop-oriented systems do not address very well.

Organic agriculture, a holistic system that focuses on improvement of soil health, use of local inputs, and relatively high-intensity use of local labor, is an admirable fit for dry lands in many ways, and the dry lands offer many benefits that would make it relatively easy to implement. And, in fact, India's National Project on Organic Farming (NPOF), launched in 2004, has given top priority to the dry lands (NPOF 2005).

\section{METHODOLOGY}

\section{Basis of study}

The review is made mostly from research work conducted elsewhere, since most of the published data on organic farming comes from developed nations; but wherever possible, Indian literature is taken into account. This review is not exhaustive, but indicative on certain pertinent aspects of organic farming, which are often talked about and debated, particularly with reference to its adoption among Indian farming communities, especially under rain-fed zones.

\section{Section A}

\section{Organic farming for the dry lands of India -Ecological sustainability}

Soil and climate conditions in India's dry lands make them particularly well suited to organic agriculture. These marginal lands, with their marginal soils, tend not to respond well to intensive farming practices. They are actually better suited to low-input farming systems that make ample use of biodiversity (Sharma 1998). In turn, organic farming, with its central focus on maintaining 
International Journal of Agriculture and Environmental Research

ISSN: 2455-6939

Volume: 07, Issue: 02 "March-April 2021"

and improving soil health, its avoidance of pollutants, and its reliance on local inputs and labor, can materially advance the economic and ecological health both of the dry lands and of the people who live there.

To begin with, semi-arid and arid dry land soils typically are poor in water-holding capacity as well as organic matter (Sharma 2000). In some areas depth of soil is another limiting factor for agricultural production. Addition of organic matter, a cornerstone of organic farming practices, will not only improve the physical condition of these dry land soils but also greatly improve their ability to supply balanced plant nutrients.

Furthermore, as stated in the introduction, dry lands desertification is increasing at an alarming rate due to over-exploitation of natural resources. This is mainly because of productionenhancing technologies that are inappropriate in dry lands (Dhir 1997). For example, use of tractors increases wind erosion and damages natural regeneration of trees and grasses. Over-use or improper use of canal irrigation can cause water logging and salinity (not to mention malaria epidemics). Excessive groundwater pumping has decreased the groundwater table drastically in tube well-irrigated areas. In many locations where intensive-input agriculture systems are followed, soil fertility is decreasing and certain severe crop pests are becoming resistant to synthetic pesticides. These all are indicators of improper land use leading to desertification; adoption of organic farming practices suitable for dry lands can help to ameliorate these conditions.

Another serious problem in dry lands is the lack of sufficient food security or economic opportunity for the many people who live there. The population in these dry lands areas is currently growing at a rate of $2.8 \%$ per year. Yet, under current practices, many dry land farmers are unable to earn a year-round livelihood in their own villages. The consequent migration of villagers to cities and nearby states for livelihood during drought further imbalances the economic development of these dry lands. Since organic farming is labor-intensive and relies on local inputs, it can provide both improved local food security and ample opportunities for local employment and proper utilization of this precious human resource (Gupta and Sharma 1996).

To be sure, many farmers resist implementing organic systems because they fear a drop in productivity and thus income, during the years while synthetic fertilizer/pesticide use is discontinued and the soil is gradually built up by organic means. However, the longest transition periods occur where pesticide use has previously been greatest. And, because of the lack of a reliable water supply, average fertilizer use in the semi-arid, rain fed dry lands--67\% of India's agricultural area--is already very low $(36.4 \mathrm{~kg} / \mathrm{ha}$ ) compared to the national average of 76.8 $\mathrm{kg} / \mathrm{ha}$. In the actual desert areas, fertilizer use is negligible (FAI 1998). Pesticide use is also very low. Furthermore, large parts of the dry lands are still categorized as "virgin," meaning no 
synthetic inputs have been used there to date. This makes a quick shift to organic agriculture, with no drop in productivity, much easier.

Due to climatic variability, farming systems in dry lands traditionally mix crops, trees, animals, grasses etc. Such diversified systems have been found efficient in nutrient recycling and restoration of soil fertility, the basic aims of organic farming; they minimize pest incidence as well. Furthermore, India's traditional farmers possess a rich body of wisdom, based on long observation and practice, concerning soil fertility management and pest control; this can be drawn on to further strengthen organic systems (Sharma and Goyal 2000). These two factors will also aid the quick development of more efficient, more productive organic farming systems in these areas.

In terms of input supply, the dry lands are very rich in local resources suitable for supporting organic farming:

- Some of the best sources of biopesticides, like neem (Azadirachta indica), Karanji (Pongimia pinnata), and Calatropis spp, are abundantly available in drylands (Rajeshwar Rao 1999).

- Similarly, minerals like rock phosphate, gypsum and lime are available naturally in large quantity in Rajasthan. These minerals help improve soil conditions and supply plant nutrients.

- Finally, properly handled and aged animal and human wastes are among the best organic fertilizers available traditional dry land farming systems are well supplied with both. Indeed, in such areas animal populations are growing at 1.5 to $2.5 \%$ per year (Purohit 1998).

\section{Section B}

\section{Strategic Approach for promoting organic farming in dry lands}

As shown above, there is immense potential for adoption of organic farming in India's dry lands (Sharma 2001). Socio-economic and ecological reasons also favor it (Arora and Mohan,1986): many aspects of dry lands that would pose constraints for the intensive agriculture system of the Green Revolution can be converted into opportunities for organic farming. The following specific steps would go a long way towards promoting this development.

\section{Popularize organic farming without compulsion of certification.}

In dry lands, farmers are very poor and are largely unable to afford the cost of certification programs. Promoting certification as a universal requirement of organic farming has thus had a 
negative impact on its adoption by smallholders in these areas. A more appropriate approach for dry lands, at least during a certain initial period until the industry is established, would be to promote non-certified organic farming with a goal of providing local employment and improving local/regional food security rather than developing export crops.

\section{Promote ley farming.}

In India's dry lands, rotation of grasses and food grains is known as ley farming. This system is traditional; research by the Central Arid Zone Research Institute (CAZRI) has validated it as one of the best options for fertility restoration in these regions (Muthana et al. 1985).

\section{Integrate efforts of supporting agencies.}

Several government agencies and NGOs are working individually to promote organic farming. This individual approach, however, may result either in lack of adequate funding or lack of adequate knowledge of organic farming and/or marketing techniques. For example, rural ministries have a scheme of "margin money" in which they subsidize $25-30 \%$ of loans made to establish vermin composting units; but they are unable to ensure a steady market for the produce of such units. Similarly, state agriculture departments and the institutes that make up the Indian Council of Agriculture Research (ICAR) have a wealth of information on organic farming but are unable to provide financial support for initiating such programs. Thus there is need for all related agencies to create integrated programs, linking the storehouses of technologies with financial institutions, in order to effectively promote organic farming. Since funding agencies always have the financial upper hand, they must take the lead to ensure sufficient technology backup and marketing of these products. This could be affected through a coordinating committee with representatives from all concerned organizations.

\section{Encourage decentralized input supply.}

Local, decentralized production of all inputs for organic farming should be encouraged not only so that local resources can be utilized but also so that village-level employment can be generated. Locally produced inputs are also much less likely to be adulterated. All of this organic input production should be legally categorized as cottage industry. Subsidies or micro-financing to help set up small-scale input production units that meet local requirements could be provided to village cooperatives and self-help groups (that is, informal groups of people with a joint livelihood system and a common bank account). Banning inter-state transportation of organic inputs could be another effective method for keeping such production local.

\section{Adopt improved methods of composting.}


In general, farmers understand the importance of adding organic matter to drylands soils, but the majority apply undecomposed animal and crop wastes. This not only reduces the availability of nutrients to plants but also invites several pests. It would be better to apply these materials after composting them (Durgude et al. 1996) with any of several suitable methods (Table 3). Because these composting methods would help reduce disease and improve local sanitary conditions, they could be popularized and financially supported under India's existing "Clean village scheme." This scheme, sponsored by the government's Ministry of Rural Development and executed by state governments and volunteer organizations, focuses on safe disposal and use of human and animal wastes as a means of improving hygiene and health at the village level.

\section{Increase public awareness and build capacity.}

Conferences, seminars, and farmers' fairs may be organized to raise awareness and encourage adoption of organic farming. Programs demonstrating how to establish organic systems, and training in how to produce and manage organic inputs, may be started at the village level. Under the NPOF, sufficient provision has been made to train farmers for organic production and internal control and to develop both model organic farms and a nationwide network of organic service providers (to provide guidance, establish farmers' groups and arrange organic inputs). However, most of these programs focus on irrigated areas because of ensured success and export possibilities. A rational allocation policy for drylands is needed.

\section{Subsidize organic inputs and produce.}

Subsidies may be provided for organic inputs and produce while the industry is still getting established. In India, subsidies are mainly provided by the national government and channeled through state agriculture departments; the technique is well-tested, having already been used for the synthetic fertilizer and pesticide industry. Indeed, subsidies have been provided for setting up biofertilizer and vermicomposting units under NPOF and for setting up export schemes under NPOP. Additional subsidies could be provided for:

- Setting up organic input production units for composting, biopesticides etc.

- Compensating organic farmers during the period of conversion to organic techniques, to compensate for yield reductions if any.

- Establishing village-level grading and packaging units for organic produce.

- Developing local and regional marketing infrastructure for organic produce in dryland areas, where regional/local food security is more important than crops for export.

Promote high-value crops. 
The dryland climate favors quality production of several spices and medicinal plants that are in already in great demand both nationally and internationally (Table 4). Furthermore, demand for organic versions of these high-value products is increasing. Thus, once the local market is well established and the potential for growing crops for export has increased, they may be promoted to dryland farmers as excellent plants to include in the overall design of their organic system.

\section{Develop organic farming clusters of villages.}

Since the drylands are already an area of focus for governmental development programs based on a watershed approach, clusters of villages previously established for such programs (Khan 2002) may be converted into organic clusters of villages by providing technical support. This will be cost-effective and make the eventual certification process of organic produce easier for these villages once the local organic produce market has been well established.

\section{Develop certification programs and marketing chains.}

Ultimately, once the drylands organic agriculture industry is strong, cost-effective facilities for sale of certified organic produce in regional and global markets may be created. The cost of certification should be met by the exporters.

\section{Conduct ongoing research on organic systems.}

ICAR institutes and State Agriculture Universities have already done much research on various components of organic farming such as vermicompost, biopesticides, biofertilizers, and agroforestry. However, more research is needed to integrate these efforts and assess their effects. Ongoing research is needed on all the following aspects of organic agriculture simultaneously (Sharma 2001):

- Survey and scientific validation of traditional organic farming practices.

- Use of locally available resources for production of manures and biopesticides.

- Assessment of economic and ecological returns from organic vis-à-vis intensive agriculture systems.

\section{CONCLUSION}

Due to low, erratic rainfall and poor soils in India's dry lands, farming systems based on synergism with nature, and thus essentially "organic," have been followed for centuries. This opens the door to immense possibilities for improving the soil health and overall environment, and providing sustainable livelihoods in these areas, by updating these age-old systems with modern research and techniques. The key to achieving this is enhanced collaboration and cooperation among all the agencies and programs that have an interest in supporting these goals. 
International Journal of Agriculture and Environmental Research

ISSN: 2455-6939

Volume: 07, Issue: 02 "March-April 2021"

By working together, the goals of promoting organic practices, improving soil health and local food security and, ultimately, creating markets for organic produce both regionally and globally, can be realized for the benefit of all of India.

\section{REFERENCES}

1. Arora, Y. K. and S. C. Mohan. 1986. Agrihorticulture systems for watershed management. Indian Journal of Soil Conservation 14(3):100-104.

2. Balak Ram. 2003. Impact of human activities on land use changes in arid Rajasthan: Retrospect and Prospects. In Human impact on desert environment, eds. P. Narain, S. Kathju, A. Kar, M. P. Singh and Praveen-Kumar, 44-59. Jodhpur, India: Scientific Publishers.

3. Dhir, R. P. 1997. Problems of desertification in the arid zone of Rajasthan, India. Desertification Control Bulletin 27:45-52.

4. Durgude, A. G., B. P. Role, V. A. Joshi, and J. D. Patil. 1996. Effect of different organic manures on yield, nutrient uptake and moisture utilization by rabi sorghum. Indian Journal of Dryland Agriculture Research and Development 11(2): 90-92.

5. Fertiliser Association of India (FAI). 1998. Fertiliser statistics 1997-98. New Delhi: The Association.

6. Gauri, P. V. S. M. 2005. National Programme for Organic Production. In Proceedings: National Seminar on National Policy on Promoting Organic Farming, 44-48. Ghaziabad (India): National Centre of Organic Farming.

7. Gupta, J. P. and A. K. Sharma 1996. Agrihorticulture in arid region for stability and sustainability. In Agroforestry systems for degraded lands, eds. P. Singh et al., 164-167. New Delhi: Oxford and IBH.

8. Khan, M. A., ed. 2002. Watershed management for sustainable agriculture. Jodhpur (India): Agrobios.

9. Purohit, M. L. 1998. Impact of recent spurt in human and livestock population on India arid ecosystem. In Desertification control in the arid ecosystem of India, eds. S. Singh and A. Kar, 198-204. Bikaner (India): Agrobotanical Publishers.

10. Muthana, K. D., S. K. Sharma and L. N. Harsh. 1985. Study on silvi-pastoral system in arid zone. My Forest 21(3):233-238.

11. National Project on Organic Farming (NPOF). 2005. Organic farming newsletter 1(1): 918.

12. Rajeshwar Rao, B.R. 1999. Medicinal plants for dry areas. In Sustainable alternate land use systems for drylands, eds. R. P. Singh and M. Osman, 139-156. Dehradun (India): Oriental Enterprises.

13. Sharma, A. K. 2001. A handbook of organic farming. Jodhpur (India): Agrobios. 
International Journal of Agriculture and Environmental Research

ISSN: $2455-6939$

Volume: 07, Issue: 02 "March-April 2021"

14. Sharma, A. K. and R. K. Goyal. 2000. Addition in tradition: Agroforestry in the arid zone of India. LEISA India 2(3):19-20. 